\title{
Re-Contextualizing Unemployment and National Security in Nigeria
}

\author{
Hyacinth N. Iwu ${ }^{1}$ \\ ${ }^{1}$ Department of Political Science and Public Administration, Adekunle Ajasin University, Akungba-Akoko, \\ Nigeria \\ Correspondence: Hyacinth N. Iwu, Department of Political Science and Public Administration, Adekunle Ajasin \\ University, Akungba-Akoko, Ondo State, Nigeria. Tel: 234-70-6154-6003. E-mail: hymanfrantz@yahoo.com
}

Received: December 19, 2014 Accepted: March 10, 2015 Online Published: July 29, 2015

doi:10.5539/jsd.v8n6p231 URL: http://dx.doi.org/10.5539/jsd.v8n6p231

\begin{abstract}
Unemployment is largely blamed for the intractable security challenges in Nigeria. More worrisome is that population growth adds 4.5 million youths into the labour market every year that largely begs for the public sector attention as presently conceptualized. Previous studies have focused on national job creation to manage employment challenges. This study argues on the contrary and sues for re-conceptualization of the concept of unemployment. The problem is that unemployment is major buzzword for assessing government in Nigeria. Unless re-conceptualized, unemployment will continue to pose serious challenges to national security. A number of strategies are highlighted to contain the challenges.
\end{abstract}

Keywords: unemployment, national security, human resources, employment, entrepreneurship

\section{Background}

There is need to link unemployment to the matrix of national security in order to find explanatory framework for this study. Burgess (2008:60) posited that despite the fact that fears, anxiety, danger and doubt are fundamental social and individual experiences; the scholarly study of security has fundamentally been limited to the field of international studies, associated primarily with the status of nation-state in relation to each other. McNamara (1968:149) who posited that security is development and without development there can be no security further reinforces the nexus between unemployment and insecurity.

This paper departs from the focus of earlier works on Nigeria that largely rest on traditional conception of national security such as Ekoko and Vogt (1990); Jonah (2008); Isa (2007) and Hutchful (2004). However, it is important to acknowledge that some works that tend to move away from traditional approach to the study of national security in Nigeria such as Nnoli (2006); Pogoson (2013); Nwolise (2012) and Abolurin (ed) (2011), focused on other issues and not on establishing a nexus between population growth, unemployment and national security. At the global context, Burgess (2008:60) captured a wide range of burgeoning literature on national security which revisited the traditional cold war notion of security that see the state as both the object of security and the primary provider of security as shown by Aggestam and Hyde-Price (2000); Alkire (2003); Baldwin (1995, 1997); Booth (2005b); Brown (1997); Buzan (1991a, 1991b); Dalby (1997, 2000); Der Derian (1993); Dillon (1996); Huysmans (1998); Kaldor (2000); Lipschutz (1995); Rothchild (1995); Tickner (1995); Waever (1997, 2000); Williams (1994) and Wyn Jones (1999). These works show a general consensus among both scholars and practitioners that a wide range of security threats, both new and traditional, confronts states, individuals and societies. However, the stance of this present work is to show that the challenge to human insecurity in Nigeria emanates from the state of poverty, which is largely caused by overdependence on government institutions to provide employment. This study re-contextualizes, examines unemployment problem, interrogates nexus between unemployment and national security and highlights how to contain the challenges.

\section{Re-contextualizing Unemployment}

We can assume that before now joblessness was understood as a personal problem. The assumption is based on the fact that prior to exploitation of oil in commercial quantity in Oloibiri in 1956 (Ogunlowo 2008:48-120), agriculture provided the engine of employment both formally and informally to every prospective individual who want to work in that sector in Nigeria. Staying without job in any sense was certainly regarded as bad luck for anyone who had no physical deformities. With the emergence of oil (extractive industry) and elaborate (not robust) bureaucracy, employment in the non-agricultural sector gained momentum. 
International Labor organization (ILO) defined unemployment as numbers of the economically active population who are without work but available for and seeking work, including people who have lost their jobs and those who have voluntarily left work (World Bank, 1998: 63). No doubt youth employment has been a catchword for commentators on political issues but there is need to re-contextualize employment and unemployment. Employment tells us something about service and pay. On this premise employment is usually associated with someone working for, and being paid for the service rendered. Employment loses its meaning from the common usage when an individual is engaged in personal work. He/she hardly perceive it as providing service for the recipient of his/her products, and money paid for the products as wages, earnings, income or salary. This is what this study refers to as misconception of employment. Its narrow definition only links it to an 'out-door' work and wages received in that regard. Unemployment on the other hand refers to being without a job; job loss; idleness; redundancy; joblessness. There is need to examine if there are insufficient jobs in Nigeria. Unemployment are constantly used by political commentators to mean that the 'out-door' person, organization or government has failed to provide or give job to someone, therefore, denying the person the opportunity to receive pay, salary, income, earnings, or wages. When employment is narrowly defined in relation to someone being paid by the out-door-person especially government, we have many unemployed people who constitutes the army of the unemployed. This is what I also refer to as misconception of unemployment. Decent Work Country Programme 2012-2015, November 2011 draft, argued that Nigeria has had a decade of jobless growth given that years of economic growth has not translated to more wage employment opportunities and poverty alleviation. Narrow conception of employment in relation to government was prevalent in United States (US) for over 150 years despite the supposed liberal orientation of American culture. Writing about labour legislation from its inception Orren (1991) posited that US defined all able-bodied individuals without independent wealth as workers who could be subject to criminal charges for not selling their labour in the marketplace. This notion subsisted until well into twentieth century. We strongly argue that it is erroneous for any scholar or individual to hold the notion in Nigeria. US can experiment such because it has the indigenous technological base for its industrial growth and self restrained birth control unlike Nigeria that lack such creativity and grappling with unrestrained fertility rate that produces more population than its labour market can accommodate. This study therefore argue that unemployment can be said to be present when an individual refuses to engage in any work that provides him/her a means of living either of his/her own or that of outsider whether public or private. And employment can be said to be present when an individual engages in any work that provides him/her a means of living either of his/her own or that of outsider whether public or private.

\section{Unemployment and Employment Prognosis}

Nigeria government bought the idea of responsibility for job creation and in 2003 created National Economic Empowerment and Development Strategy (NEEDS) as one of the reform policy entrusted with the responsibility to establish, supervise small and medium term scale enterprise development agency of Nigeria (SMEDAN) and National Agency for Poverty Eradication Project (NAPEP) (Amadi and Ogwo 2004, Sheidu 2004). NEEDS noted that the economy had experienced growth without commensurable increase in job opportunities. Although the economy recorded an average of 9.8 percent of GDP growth per annum between 2002 and 2010, the official unemployment rate for the working age population ranged between 12 and 15 percent between 2002 and 2007. Poverty has been exacerbated by the persistently high unemployment levels. Female unemployment rate show 12-14 percent, higher than male 10-12 percent (Federal Republic of Nigeria 2009). Youth unemployment rates are twice as high as the national unemployment rate which stands at $19 \%$. With the official rate of unemployment of 19.7 percent and more than 71 million people in abject poverty, Nigeria is hardly on track to meet the millennium development goal (MDGs), particularly as it targets reduction of extreme poverty and hunger (African Development Bank 2010). Okonjo-Iweala and Osafo-Kwaako (2007:16) noted the effort by government under the military rule to provide employment as thus:

Rapid public sector recruitment under military administration resulted in an oversized and under skilled work force in which employees often did not have the appropriate technical skills needed for their assignment. For example, about 70 percent of workers in the Ministry of Finance were low level staff clerks, cleaners with secondary education or equivalent.

However, the figure below shows the population figures in relation to unemployment in Nigeria from 1985-2011: 


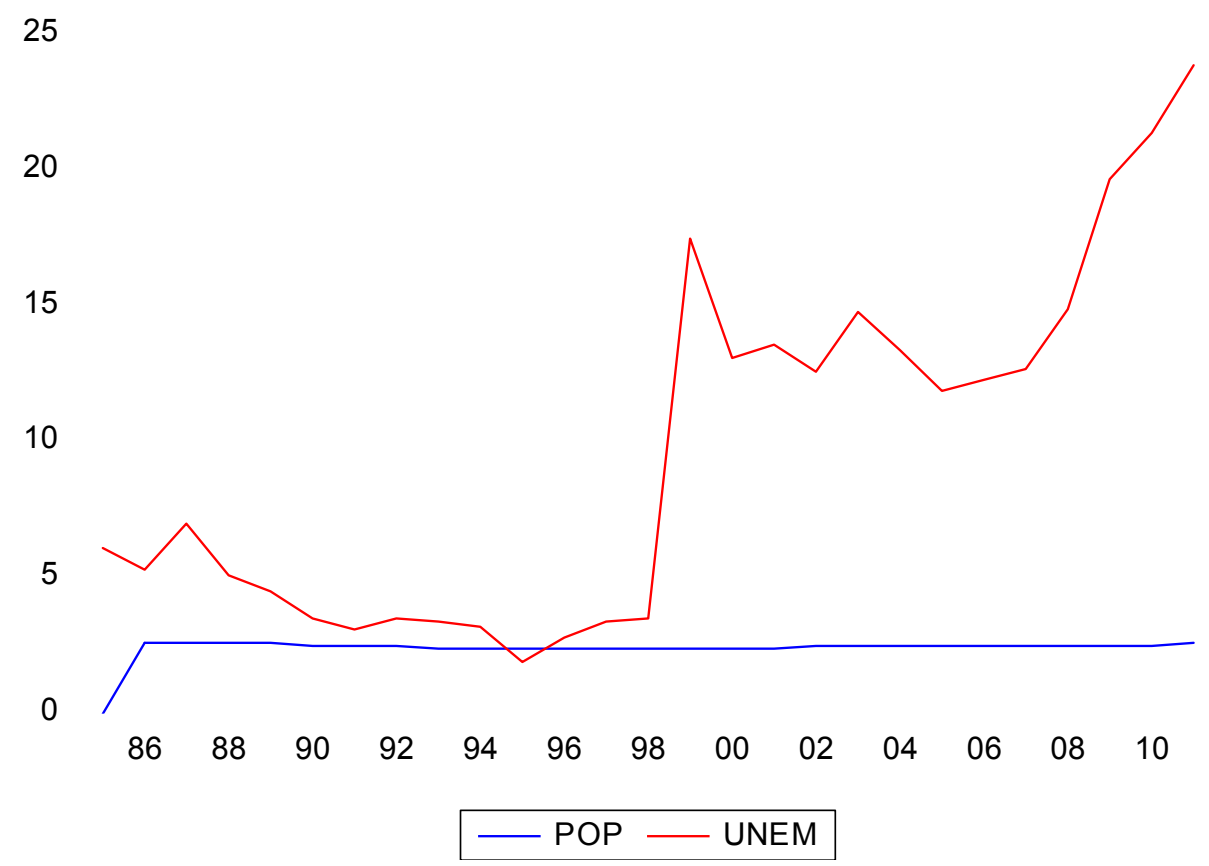

Figure 1. Unemployment and population growth rate in Nigeria 1985-2011

Source: the data used to produce this figure by the author is from The National Bureau of Statistics 2010.

Unemployment and population growth are among the economic challenges confronting developing economies like Nigeria. This trend will continue as government takes the sole responsibility of employment. Posing more threat as Nigeria has 14.4 million unemployed graduates which excludes those with secondary school certificates eligible to seek employment in the labour market. This complexity reflects in the works of Edgar (1974:10) and Carson, Thomas and Hecht (2002: 110-129). Edgar distinguished among the five following forms of underutilization of labour:

1) Open unemployment. Both voluntary (people who chose not to work even when they could qualify, implying some means of support other than employment) and involuntary.

2) Underemployment. Those working less (daily, weekly, or seasonally) than they would like to work.

3) The visibly active but underutilized. Those who would not normally be classified as either unemployed or underemployed by the above definition, but who in fact have found alternative means of 'marking time' referred to as disguised underemployment.

4) Hidden unemployment. Those who are engaged in 'second choice' non-employment activities, perhaps notably education and household chores, primarily because job opportunities at other levels are not available

5) The prematurely retired. This phenomenon is especially apparent, and steadily growing in the civil service. In many countries retirement ages are falling at the same time that longevity is increasing. Premature retirement serves as a means of creating promotion opportunities for some of the large numbers pressing up from below.

The analyses of the above conjectures show the complexity of unemployment. Arguably those people who engage in part-time teaching, house boys and gardeners, and those who teach in most private nursery, primary and secondary schools but who are graduates can be grouped into hidden unemployment as shown above. The table below Shows unemployment rate for each State in Nigeria: 
Table 1. Unemployment rates at the state level in Nigeria 2007-2011

\begin{tabular}{|c|c|c|c|c|c|}
\hline STATE & 2007 & 2008 & 2009 & 2010 & 2011 \\
\hline Abia (S) & 25.1 & 11.9 & 14.5 & 22.8 & 11.2 \\
\hline Adamawa & 21.5 & 13.5 & 29.4 & 24.6 & 33.8 \\
\hline Akwa-Ibom & 18.0 & 11.1 & 34.1 & 27.7 & 18.4 \\
\hline Anambra & 14.9 & 7.3 & 16.8 & 10.8 & 12.2 \\
\hline Bauchi $\mathbf{~}$ & 20.5 & 6.9 & 37.2 & 27 & 41.4 \\
\hline Bayelsa & 21.9 & 67.4 & 41.5 & 27.4 & 23.9 \\
\hline Benue $\square$ & 7.9 & 7.8 & 8.5 & 6 & 14.2 \\
\hline Borno — & 12.5 & 11.8 & 27.7 & 26.7 & 29.1 \\
\hline Cross-River & 32.8 & 18.9 & 14.3 & 27.9 & 18.2 \\
\hline Delta & 22.9 & 11.5 & 18.4 & 27.9 & 27.2 \\
\hline Ebonyi & 7.9 & 5.1 & 12 & 25.1 & 23.1 \\
\hline Edo & 14.8 & 15.6 & 12.2 & 27.9 & 35.2 \\
\hline Ekiti & 11.4 & 11.6 & 20.6 & 28 & 12.1 \\
\hline Enugu & 14.1 & 10.5 & 14.9 & 28 & 25.2 \\
\hline Gombe $\mathbf{~}$ & 16.9 & 7.9 & 32.1 & 27.2 & 38.7 \\
\hline Imo & 28.3 & 17.4 & 20.8 & 28.1 & 26.1 \\
\hline Jigawa & 27.0 & 5.9 & 26.5 & 14.3 & 35.9 \\
\hline Kaduna $\mathbf{a}$ & 8.7 & 12.7 & 11.6 & 12.4 & 30.3 \\
\hline Kano $\mathbf{a}$ & 10.1 & 5.8 & 27.6 & 14.7 & 21.3 \\
\hline Katsina $\square$ & 10.9 & 11.8 & 37.3 & 11 & 28.1 \\
\hline Kebbi - & 1.3 & 16.5 & 12 & 10.7 & 25.3 \\
\hline Kogi & 14.6 & 16.4 & 19 & 9.5 & 14.4 \\
\hline Kwara & 17.7 & 10.2 & 11 & 2.7 & 7.1 \\
\hline Lagos & 13.7 & 7.6 & 19.5 & 27.6 & 8.3 \\
\hline Nasarawa & 11.8 & 17 & 10.1 & 3.4 & 36.5 \\
\hline Niger $\square$ & 4.2 & 3.9 & 28 & 11.7 & 39.4 \\
\hline Ogun & 3.6 & 5.8 & 8.5 & 27.8 & 22.9 \\
\hline Ondo & 6.7 & 6.3 & 14.9 & 28 & 12.5 \\
\hline Osun & 7.2 & 6.5 & 12.6 & 27.6 & 3 \\
\hline Oyo & 8.1 & 8.7 & 14.9 & 27.7 & 8.9 \\
\hline Plateau & 6.8 & 4.7 & 7.1 & 10.4 & 25.3 \\
\hline Rivers & 66.4 & 12.1 & 27.9 & 27.8 & 25.5 \\
\hline Sokoto & 12.3 & 5.9 & 22.4 & 15.9 & 17.9 \\
\hline Taraba $\square$ & 15.2 & 19.9 & 26.8 & 24.7 & 12.7 \\
\hline Yobe $\mathbf{~}$ & 24.4 & 12.8 & 27.3 & 26.2 & 35.6 \\
\hline Zamfara & 19.1 & 16.4 & 13.3 & 14.5 & 42.6 \\
\hline FCT (Abuja) & 47.8 & 8.7 & 21.5 & 11.8 & 21.1 \\
\hline Nigeria & 12.7 & 14.9 & 19.7 & 21.4 & 23.9 \\
\hline
\end{tabular}

Source: General Household Survey Report/NBS/CBN Survey. m states in the northern Nigeria

While Osun State has the lowest percentage of 3, Zamfara State has the highest of 42.6 per cent in 2011; it is difficult to give specific reason why there are variations from each State. For example, Benue State showed single digits from $2007-2010$ and entered double digits in 2011. The State is one of the States in which most of the people are engaged in agriculture as a means of sustenance until when they began to turn to government as provider of employment. Diallo, Foko, Nzau, Eyeghe and Ovedraogo (2013: 119-120) posits that almost 1 billion people live in Africa, a figure forecasted to be more than double to 2.3 billion in 2050. 200 million of its population is youths-young people ages 14-25. And by 2040 its workforce will be higher than China's or India's. NBS, indicate that Nigeria has a youth population of approximately 80 million, comprising 60 per cent of the total population. It goes without saying that Nigeria shares 40 per cent of the youth population in Africa. 
It is imperative to acknowledge that Nigerian government since 2011 has intensified effort to create jobs for the youths and graduates from tertiary institutions including financial grants to uplift some private enterprises and the creation of new ones through its empowerment loan by Bank of Industry (BoI) and YouWin programme launched by President Jonathan on October 21, 2011. This present work argues that the creation of job through YouWin programme is highly problematic because the fund is non-refundable and interest free finance therefore no monitoring after the funds were disbursed to the winners. More of these funds are won by people who know how to write mere business proposals but later the funds were used to purchase cars, houses and even travel to foreign countries rather than create jobs. However, the coordinating Minister of the Economy and Minister of Finance stated that 1 million to 10 million naira was distributed to 1,200 winners. The breakdown shows that 53 per cent of the winners were existing businesses while 47 per cent were new businesses. The assumption is that YouWin is expected to provide at least 80,000 to 120,000 jobs for the unemployed youths. The disbursement goes thus:

While there were 300 National Award Winners, there were also 180 Zonal Merit Winners (30 per geopolitical zone), and 720 Ordinary Merit Winners picked from the country's six geopolitical zones; North-Central (204), North-East (167), North-West (170), South-East (184), South-South (194), and South-West (281).

No doubt BoI is making some effort to create jobs, however, since these jobs are often temporary, such as graduates who work under Federal Roads Maintenance Agency (FERMA) as casual workers; some are in form of loan granted to the graduates to start their own business. For example the Ministry of Trade and Investment indicated that BoI has created over 335,000 jobs through the loans made available to Nigerians. Over 139,371 employed graduates have taken part in skill acquisition in vocational, technical and agricultural sectors; over 75,640 candidates benefited from a programme on entrepreneurial skills for graduates of tertiary institutions; National Directorate for Employment (NDE), provided soft loans to 4,379 candidates to set up micro and cottage enterprises; 3,255 private jobs for graduates from tertiary institutions were created by the Ministry of Labour and Productivity; and the ministry in conjunction with NDE organized job fair where over 53,925 unemployed people were offered employment counseling services at various job centres (Umukoro 2012: 36). Truly, this is a strident effort, but not adequate if employment is seen as government sole responsibility.

We conjecture on four other correlates that largely exacerbates conditions of unemployment in Nigeria, namely corruption (focus is on the processes of getting employed into most ministries), insecurity (focus is on the inhibition of mobility), the private sector (focus is on the capacity to provide employment), and academic curriculum (the focus is on the curriculum producing students without much technical skills and knowledge required for modern industrial technology). Though corruption is variously defined but Putnam, Leonardi and Nanetti (1993) offers a more inclusive insight. The work shows that corruption erodes the capacity to develop social capital, a collection of positive social attributes, such as trust, being one's brother's keeper, and a shared notion of the purpose of the existence of the larger society which are essential for a people-oriented development. Absence of these shared collective positive social attribute is largely responsible for corruption and obviously why government effort may derail. The report by Suleiman (2013:18-23) writes thus:

The money-for-job scam has drawn the ire of the National Assembly. On January 16, 2013 following a motion brought by Atiku Bagudu, a senator from Kebbi State, the Senate resolved to investigate all the recruitment exercise by all federal government agencies in the last two years with a view to punishing perpetrators of employment scams in the country. In the motion Bagudu revealed that jobs were being sold to Nigerians instead of being given to qualified people. He alleged that employment letters for the Nigerian Immigration Services are sold for between $\# 400,000$ and \#500,000 through a syndicate located at Gwagwalada and Karu in Abuja in violation of rules......another Senator Mohammed Ndume, said he once paid \#200,000 "out of compassion" to secure a job for someone in his constituency who had second class upper in Geography. Babafemi Ojudu a senator from Ekiti State (Note 1) in an interview stated that, "it has to do with some 17 young persons from my constituency who applied to the Nigeria Security and Civil Defence Corps (NSCDC), last year. According to their story, they were asked to pay \#250,000 each, which they paid. They were subsequently screened and employed. They were there for three months and they were paid for that period. But they got a letter last year asking them to report to Abuja. When they came to Abuja, their letters of employment were withdrawn. In protest they sent a protest to the President of the Senate through me because I am their representative at the Senate".

It is almost a norm in Nigeria for any government appointee who underwent through legislative screening to 
consider reserving a slot for the members whether at the state level or federal level should there be demand for employment. For example, Rose Uzoma was accused of such practice, which goes thus:

The House of Representatives also launched an investigation into the alleged lopsidedness and corruption in recruitment at the Nigerian Immigration Services. The Committee, headed by Ahmed Idris, accused the former immigration boss Rose Uzoma of secretly offering hundreds of jobs slots to key government officials and agencies, including the Presidency, the minister of Interior, and the Federal Character Commission, which assists it in violating the principles of federal character. The committee according to Idris also found that the practice was widespread among government agencies. Uzoma was subsequently removed as Immigration boss by President Goodluck Jonathan and the approval given to her to employ 4,560 people halted following the controversy (Suleiman 2013:19-24).

The recent discoveries by government agencies revealed that most ministries have ghost workers, an indication that the vacancies are filled by non-existing people. Hence this creates some kind of unemployment in the country. "Man knows man" is observed in the implementation of the subsidy reinvestment programme (SURE-P) inaugurated in 2012 in the area of job creation. We observed thus:

Some low key politicians were observed wearing shirts with SURE-P inscription who claimed that they are utilizing the slot of the members representing them in the national assembly. Their duties involved street cleaning and local security services. They see the menial job as a form of employment. To them they are holding it not because they are not engaged in private business but it is a pay for the work done during election.

Unemployment is further exacerbated by the insecurity in Nigeria. It is a truism that conditions of insecurity divert attention from other programmes of the controlling authority, and may create paucity of funds because of the resources required to contain or control it. Our analysis focuses mainly on the recent insurgency in Nigeria which has posed serious insecurity to the state. We do not want to stress the point that a lot of resources are expended on the counter-insurgency measures which would have been used for other developmental programmes. The reason is that it will be extremely difficult to posit that the monetary value expended on the counter-insurgency measures would have been used to create new industries that would have given employment to the people, since before now such funds were fleeced away for personal use. But our intension is to show that the present insurgency in Northern Nigeria is contributing to unemployment. Since Nigeria operates a federal system of government which permits the establishment of federal government agencies, and ministries in all the states of the federation, employment into these institutions is based on policy of federal character or quota system which ensures that all the federating units are represented in the bureaucracies of these institutions (Amuwo, Suberu, Agbaje, and Herault, 2004; Osaghae, and Onwudiwe, 2007; Onwudiwe, and Suberu, 2005. Ekeh, and Osaghae 1989). Many people from the southern part of Nigeria employed into these federal institutions in the northern part of Nigeria where the insurgents are operating have either resigned their employment or seek secure redeployment and there is re-entering into the labour market when redeployment is not possible. The situation applies to the indigenes of the northern states where the insurgency is most pronounced. Feeling insecure has rather sought for reposting and when that is not possible they have rather opted out of job and re-entered the labour market. Finally many others who were in their private business or self employed or have employed others under private sector but whose business have been pulled down by the insurgents both from north and other regions of Nigeria have added to the army of the unemployed in Nigeria. It goes without saying that Nigeria is going to experience situational unemployment now. Table 1 above shows that most of the states in the northern part of Nigeria ranks greater in unemployment which may not be unconnected with the level of insecurity there.

The private sector paradigm anchored on neoclassical hypothesis have provided Nigerian economic planners with overwhelmed assumption that private ownership of enterprises as against state-owned provides greater efficiency and more rapid growth. (Todaro and Smith 2011:758-761). Therefore, Nigeria has cued in and its policies targeted towards government withdrawal of economic management, leaving the private sector both to manage and also to provide employment for the people seeking job out of government bureaucracies. However, there are three types of private investment in Nigeria, namely local or indigenous private enterprise, foreign owned enterprise but cannot be categorized as multinational corporations, and multinational corporations (MNCs). While the indigenous private enterprise can absolutely be controlled under the national laws of Nigeria, the other two especially the multinational corporations operate under some form of protection under international law (Note 2). Efficiency is the watchword in the privatization of state owned 
companies, but in Nigeria, ethnic configurations of the people also plays a role in selection of core investors. Under private ownership the entrepreneur is at will to spread his employment to all the ethnic groups or may reduce the workforce, preferring any employee against the other. Thus resistance manifest during privatization in Nigeria.

Our major focus is on the capacity of private owned companies to generate employment or create jobs. The sector is visible in manufacturing, agriculture, services, banking, retail, wholesale trade, extractive industries, import, and export activities. However, most of them operate under some forms of leverage over whom to employ and the category of employee because of the requirement of technical skills, protection by international investment laws, and financial prowess. Specifically MNCs operate under certain equity shares that enhance their bargaining power over the category of staff to employ (Gilpin, 1987). MNCs are technological driven limiting the number of people to employ. The SMEs requires creativity and innovativeness to expand which is most lacking in Nigeria because of near absence of scientific based knowledge that will translate the ideas and innovation for products for the markets. At most where such ideas are translated to products the main manufacturing plants are located in the countries origin of the experts who developed such knowledge like the Lebanese and the Indians companies etc. Also their employment potentialities are curtailed blamed on epileptic power supply and lack of sustainable policy supporting indigenous business growth. Some of them like, Nigeria Textile Company and Dunlop Nigeria have either closed down or relocated to other countries.

Finally, we examine the role academic curriculum play in producing human capital capable of engendering new ideas in the economy. We argue that new ideas produce opportunities for expansion that generates employment. With increasing sophistication in technology and high demand for other services outside agricultural products, the most important factor of production has shifted to knowledge economy. The phenomenon has already gained ground in the developed countries of the world. However, some middle income countries like South Korea (Suh and Chen 2007), Singapore (Yew 2000) and India etc (Todaro, and Smith, 2011) have restructured their academic curriculum to produce graduates with adequate knowledge to produce goods and services that are not only demanded locally but are demanded in other countries. Chirot $(1985 ; 192-193)$ argued that "later industrialization could not have occurred had markets of all sorts not achieved such a high state of development in pre-industrial Europe ---- by analogy, a kind of intellectual market for new ideas, important thinkers and artists, and technological innovations". Reinert (1996:161) wrote that there is a growing awareness of the role of technology in creating economic growth. He opined that a large research programme by the organisation for Economic Cooperation and Development Technology and Economy OECD-TEP), recently brought this issue, and the underlying evolutionary theory of economic growth into focus. The academic system can be structured to give the citizenry technological skills, rather than produce graduates who are not innovative. Yew (2000:50-52) gave an idea that Singapore had to rethink its education policy towards producing graduates with critical innovativeness. In China there has been a direct policy to ensure that every child born grows up to become a resourceful person to the economy. The strategy is tailored towards ensuring a sound and useful academic curriculum for the schools and in Singapore in specific terms; female and male of higher academic standards are encouraged to marry each other so as to produce children with high intelligent quotients (IQ). Since our academic curriculum does not largely target at producing people with high creativity no matter the amount charged as tuition fees, "appropriate and requisite" knowledge will be lacking.

\section{Nexus between Unemployment and National Security}

Unemployment can impact negatively on Nigeria's national security. National security is a phenomenon (observable fact) which can be affected by so many factors. When factors such as ethnic and religious conflicts, human trafficking, drug trafficking, external threats, unemployment, population growth, etc affects negatively the desired or acceptable condition prescribe by the State, we say that the national security is threatened or there is state of national insecurity. Stolberg (2012) work showed that though there might be some similarities in the ways nations craft their national security but some nations incorporated more elements of civil society and domestic national security than others. This underscores the importance of assessing critical issues that can pose threat to national security. Therefore, we argue that when policy makers of a State decides to engage in a critical assessment of whatever situation or circumstance that will on the long or short run disrupt the existing polity, what they are doing is, giving attention to factors that can cause insecurity to the State. National security therefore is the ideal condition of a State, that is, the situation of being secured. But this secured situation can be threatened by external and internal factors. The focus of this study is on those internal factors which can pose treats to national security in Nigeria. Security means freedom from danger or anxiety. Security therefore is the 
state of being secure or means deployed to actualize it. It is not only about providing protection to the individual, physical environment, core values of a nation or other forms of national interest, but also the advancement of the quality of lives of the citizens of a country. One critical element that can easily affect the quality of lives of the people is when people who are capable and desirous to engage in work could not find work to do (unemployment) howbeit, wrongly conceptualized. The situation if not contained will lead to a high level of insecurity which manifest in form of crime, popular discontent or protest against the State, human trafficking, insurgency, child labour, drug trafficking etc. McNamara (1968:149) states thus:

In a modernizing society, security means development. Security is not military hardware, though it may include it. Security is not military force, though it may involve it...........security is development and without development, there can be no security.

In the same vein Nwolise (1985:68) argued that:

A country may have the best armed forces in terms of training and equipment, the most efficient police force, the most efficient customs men, the most active secret service agents, and the best quality prisons, and yet be the most insecure nation in the world, as result of defence and security problems from within - bad government, alienated and suffering masses, ignorance, hunger, unemployment, or even activities of foreign residents or companies.

The major problem Nigeria is confronted with is the internalized notion that it must have public sector infrastructures to accommodate citizens seeking to work in the public sector. People who are not currently engaged in the public sector feel that government has failed in its responsibility as result they are ready tools for people who want to foment trouble in the nation. Though government of Nigeria is introducing entrepreneurial studies in tertiary institutions to inculcate values of self reliance after tertiary education, yet the option is voluntary, therefore more graduates have continued to opt for public sector employment.

Nigeria government has fallen into this trap when it granted amnesty to Niger Delta Youths that majorly claimed that the move to take up arms against the State was because of government inability to provide them with employment. Some segment of Nigerian society even past political leaders and opposition parties has continued to blame the terrorist activities going on in the northeast of Nigeria to inability of the government to provide employment to the youths there. Quick reference is made to what is known as Tunisia's Jasmine Revolution of December 2010 and January 2011 that sparked the pro-democracy revolts that set the Arab street ablaze (Jama 2014:17), when a youth, Mr. Mohammed Bouazizi a Tunisian set himself ablaze because he could not secure a formal employment after graduating from High school (Nwolise 2013: 13). Though he was engaged in private job, pushing wheelbarrow to sell fruits but the quick immolation committed by him shows the level of frustration with the type of job and his standard of living. The works by Polet (2007) on the state of resistance, Fox and Gaal (2008), working out poverty, and Alters (2011) clearly show that resistance against the State has high correlation with the unemployed who feel that their state of being poor is linked to unemployment. The nexus between unemployment and national security can easily be established against the backdrop of the recent recruitment exercise carried out by Nigerian Immigration Service (NIS) in 2014. Twenty people lost their lives because of the stamped that ensured as result of large numbers of the unemployed that applied for recruitment into NIS. The situation would have resulted to a serious threat to national security if the job seekers had turned to the streets to foment trouble. Though work by Akande and Akerele (2008) shows that the informal sector is absorbing some of work force but reports also show that the informal sector is bedeviled with a lot of challenges ranging from short supply of electricity to paucity of financial capital. But the critical point to note is that people who are in private jobs and those who don't want to engage in private work combine to constitute job seekers in Nigeria. Also since there is less regulation on the conditions of service that may be applied by the informal sectors, it goes without saying that the conditions may not appeal to some graduates. This study therefore concludes that we don't need to deploy rocket science to establish that unemployment contributes to national insecurity. Brown (1987: 415-416), had argued that:

Understanding the new threats to security and economic progress will challenge the analytical skills of government. Sadly, the decision-making apparatus in most government is not organized to balance threats of a traditional military nature with those of an ecological and economic origin. Non-military threats are much less clearly defined.

Contrary to what obtains in developed countries, parties in less developed countries are not formed by people who are united for promoting national interest. Citing Edmund Burke, Langford (1981:381) posited that party can be defined as a body of men united, for promoting by their joint endeavours the national interest, upon some particular principles in which they are all agreed. Empirical evidence suggests that opposition parties do not take 
into cognizance the security implications before making critique of parties in government. In effort to win election, opposition parties have blamed party in government for the unemployment in the country. The expectations that employment would have been provided by government predisposes graduates and others not employed to being susceptible to manipulation by the political class who often find in them readymade tools for election violence. Others who engage in criminal activities argue that it is a reaction against the government that did not provide them with job. Aldcroft (1996:1-22) pointed out that the developed countries had challenges of unemployment, rather than resort to just building or creating more industries to employ the population emanating from unbridled birth rate, there was a unique family life cycle whereby abstinence from marriage and late age of marriage served to limit entrants into the labour market (Laslett 1988: 235-238). Nigerian case showcases poor people giving birth to average of five children in nuclear family thereby increasing the number of people who depend absolutely on government for not only employment but other necessities of life. These challenges cannot but call for a more rigorous research on how to situate the context of unemployment in a proper perspective. The recommendation made in the next section is as a result of the internalization of the wrong notion that government should be blamed when its citizens are not employed. We argue that it is not only imperative but instructive for the recommendations to be examined critically since government cannot extricate itself from this lock jam because of the nature of politics in Nigeria.

\section{Strategies for addressing the challenges}

1) The government of Nigeria must fund adequately vocational and technical education and students who are admitted to such schools must undersign to be self reliant after graduation but those who want to undertake conventional courses must sign that availability of employment is in relation to available chances.

2) Students who seek admission into university education must be made to undersign that there is no compulsory employment after graduation.

3) Each science based faculty or department in any tertiary institutions must exhibit on annually bases its research findings, inventions or discoveries.

4) Science and engineering studies should change their course titles to read department of motor mechanics, department of motor electrical rewires, department of car painting, house painting, brick making, house building, animal husbandry, vegetable production, fish breeding, soap making, block making etc.

5) Each social science and arts based faculty or department must through lecture or workshop show how much contextual issues within its discipline have found indigenous or local explanations. These recommendations become imperative and in fact instructive because of the obvious danger extrapolated conceptualisation poses to Nigerian State.

Because the students have been taught a special skill in either university or any other tertiary institutions, he/she will not feel shy to engage in what he/she studied in the tertiary institution. Also when people without tertiary or formal education see people with tertiary education engaged in practical work they will appreciate their form of labour. At the end the incidence of self induced frustration-aggression will stop or reduce. No doubt politicians who are in office may find it difficult to pass such legislation to law because of fear of reelection or party losing support in the next election, but it is rational for them to think there is a high correlation between employment and wellbeing of citizens and political stability. Though at theoretical level the causes of unemployment has remained contested as captured by Carson, Thomas and Hecht (2002: 110-129). The work captured a critical argument that shows the positions of the Conservatives, Liberals and the Radicals on unemployment. The synopsis is put forward as follows:

Conservatives see the present unemployment problems as largely the result of government efforts to manage labour markets. They therefore advocate minimum government involvement as the only long-run solution to joblessness. Liberal arguments hold that much of current unemployment is beyond the reach of usual stabilization policy tools. Thus new and enlarged job programmes are necessary to remove the structural limitations of the economy that have created chronic unemployment. For Radicals, unemployment is characteristic of capitalism, a natural outgrowth of the system's tendency to produce surplus labour.

\section{Conclusion}

While this debate continues, nation states should device a means most suitable to tackle unemployment challenges. For example the radicals has argued that Individuals who value their labour higher than the market does or higher than its actual contribution to output, or who simply prefer leisure to work, may be jobless; 
however, their unemployment is voluntary and not a fundamental problem demanding the policy makers attention. It goes without saying that unemployment can arise from various ways but constantly used as political tools against incumbent regime thereby flaming up insecurity in a State. This recommendation is against the backdrop that the unemployment in Nigeria in 2011 was 23.9 per cent while the poverty incidence was almost 70 per cent. According to the Coordinating Minister of the Economy and Minister of Finance, Dr. Ngozi Okonjo-Iweala, unemployment at about 24 per cent and youth unemployment of about 37.5 per cent remain a major challenge, more so as the number of new entrants in the labour force each year is projected to rise above eight million by 2015. It is clear that the economy is producing well below full employment output with all the socio-economic consequences for the country (Ekpo 2012: 43). Nigerian state will continue to grapple with unemployment as long as increase in longevity among black which has made redundancy unattractive as means of creating space for new employment and people retired from government but still very young in age nurses grudges against government and easily join the opposition against incumbent government. Consistent demand also for increase of wages by labour will definitely result to decrease in demand for more labour. Importantly as long as technological innovation will continue to shrink physical labour, States must re-strategize its approach to unemployment and employment. Finally as long as there will be unbridled population growth there must always be insufficient space to employ new job seekers.

\section{References}

Abolurin, A. (Ed.). (2011). Nigeria's national security: issues and challenges. Ibadan, John Archers.

African Development Bank. (2010). Federal Republic of Nigeria, Extension of 2011 of the 20052009 Country Strategy Paper. Regional Development, West Africa.

Aggestam, L., \& Hyde-Price, A. G. V. (2000). Security and identity in Europe: exploring the new agenda. New York: St Martin's.

Akande, S. O., \& Akerele, W. O. (2008). Employment generation in the informal sector of Nigerian economy. Ibadan: Nigerian Institute of Socialand Economic Research NISER.

Aldcroft, D. H. (1996). Rich nations - Poor Nations: The penalty of Lateness. In D. H., \& R. E. Catterall Aldcroft (Eds.), Rich Nations - Poor Nations: The Long-Ruu perspective (pp. 1-22). US Brookfield.

Alkire, S. (2003). A conceptual framework for human security, CRISE Working Paper 2, Centre for Research on Inequality, Human Security and Ethnicity (CRISE), University of Oxford.

Alters, S. M. (2011). World poverty. New York: Gale Cengage Learning.

Amadi, S., \& Ogwo, F. (2004). Contextualizing NEEDS, economic and political reforms in Nigeria. Lagos, HURILAWS \& CPPR.

Amuwo, K., Suberu, R. T., Agbaje, A., \& Herault, G. (2004). Federalism and political restructuring in Nigeria. Ibadan: Spectrum Books Ltd.

Baldwin, D. A. (1995). Security studies and the end of cold war. World Politics, 48, 117-141. http://dx.doi.org/10.1353/wp.1995.0001

Baldwin, D. A. (1997). The concept of security. Review of International Studies, 23(1), 5-26. http://dx.doi.org/10.1017/S0260210597000053

Booth, K. (Ed.). (2005). Critical security studies and world politics. Boulder: Lynne Rienner.

Brown, L. (1997). Redefining national security. Worldwatch Paper. Washington: Worldwatch Institute.

Brown, L. R. (1987). Redefining national security. In J. Fahey \& R. Armstrong (Eds.), A peace reader: Essential readings on war, justice, non-violence and world order. New York: Paulist Press.

Burgess, J. P. (2008). Non-military security challenges. In C. A. Snyder (Ed.), Contemporary security and strategy (pp. 60-78). New York, Palgrave Macmillan.

Buzan, B. (1991a). New patterns of global in the twenty-first century. International Affairs, 67, 431-451. http://dx.doi.org/10.2307/2621945

Buzan, B. (1991b). People, States and fear: an agenda for international security studies in the post-cold war era (2nd ed.). Boulder: Lynne Rienner.

Carson, R. B., Thomas, W. L., \& Hecht, J. (2002). Macroeconomic issues today: Alternative approach. London: M. E. Sharpe.

Chirot, D. (1985). The rise of the West. American Sociological Review, 50. http://dx.doi.org/10.2307/2095408

Dalby, S. (1997). Contesting an essential concepts: reading the dilemmas in contemporary security discourse. In K. Krause, \& M. C. Williams (Eds.), Critical security studies: concepts and cases. Minneapolis: University 
of Minnesota Press.

Dalby, S. (2000). Geopolitical change and contemporary security studies: contextualizing the human agenda. Working Paper No. 30, Vancouver: Institute of International Relations. The University of British Columbia.

Der Derian, J. (1993). The value of security: Hobbes, Marx, Nietzsche, and Baudrillard. In D. C. M. Dillon (Ed.), The political subject of violence. Manchester: Manchester University Press.

Diallo, A. B., Foko, B., Nzau, G., Eyeghe, A., \& Ovedraogo, A. (2013). Putting youths to work. In Agnes S., \& Mthuli N. (Eds.), One billion people one billion opportunities: building human capital in Africa (pp. 119-128). Washington D.C. Communication Department Incorporated.

Dillon, M. (1996). Politics of security: towards a political philosophy of continental thought. London: Routledge. http://dx.doi.org/10.4324/9780203288771

Edgar, O. E. (1974). Employment in developing countries: reports on a Ford Foundation study. Columbia University Press.

Ekeh, P. P., \& Osaghae, E. E. (1989). Federal character and federalism in Nigeria. Ibadan: Heinemann Educational Books Nigeria Ltd.

Ekoko, A. E., \& Vogt, M. A. (1990). Nigerian defence policy: issues and problems. Lagos, Maithouse Press ltd.

Ekpo, A. H. (2012). Unemployment: Nigeria's looming time bomb. Tell October, 1(39), 43.

Federal Republic of Nigeria. (2009). National action plan on employment creation 2009-2020. Abuja, Federal Ministry of Labour and productivity.

Fox, L., \& Gaal, M. S. (2008). Working out of poverty: Job creation and the quality of growth in Africa. Washington D. C. The World Bank. http://dx.doi.org/10.1596/978-0-8213-7442-9

Gilpin, R. (1987). The political economy of international relations. Princeton.

Hutchful, E. (2004). Reforming the security sector in Africa: an overview. University of Ibadan, the Centre for Peace and Conflict Studies. Monograph.

Huysmans, J. (1998). Security: what do you mean? From concept to thick signifier. European Journal of International Relations, 4, 226-255. http://dx.doi.org/10.1177/1354066198004002004

Isa, A. A. M. (2007). National Defence College and Nigeria's National Security. University of Ibadan. First University of Ibadan/National Defence College Distinguished Lecture. Monograph

Jama, T. A. (2014). Tunisia's triumph: with dashed hopes in the face of the Egyptian crisis and lingering lawlessness in Libya, Tunisia remains the sole beacon of hope of the Arab Spring in North Africa following the signing of its new constitution. News Africa May 31. Vol 3. No 2 Special report.

Jonah, G. J. (2008). The Maritime Dimension of Nigeria's National Security. Second University of Ibadan/National Defence College Distinguished Lecture. Monograph

Kaldor, M. (2000). Global insecurity: restructuring the global military sector (Vol. 3). London: Printer

Langford, P. (Ed.). (1981). The writings and speeches of Edmund Burke. Oxford: Clarendon Press.

Laslett, P. (1988). The European Family and Early Industrialization. In J. Baechler, J. A. Hall, \& M. Mann (Eds.), Europe and the Rise of Capitalism. Oxford: Blackwell.

Lipschutz, R. D. (1995). On security. New York: Columbia University Press.

McNamara, R. (1968). The essence of security. Reflections in Office. New York: Harper and Row.

Nnoli, O. (2006). National security in Africa: a radical perspective. Enugu, SNAAP Press ltd.

Nwolise O. B. C. (2013). Implications of the Arab-Spring for national security in the West African sub-region: The role of the Nigerian army. Ibadan: Gold Press Limited

Nwolise, O. B. C. (1985). Nigeria's defence and security system today. In U. Eleazu (Ed.), Nigeria: The First 25 Years. Ibadan: Heinemann.

Nwolise, O. B. C. (2012). Spiritual dimension of human and national security. University of Ibadan, Faculty of the Social Sciences. Monograph

Ogunlowo, A. (2008). Before the beginning: blessed with abundant natural and human resources, Nigeria had so much promise and looked poised to achieve greatness until oil export began and brought with it too much easy money — and the curse of the black gold. Tell February, 18(Special Edition).

Okonjo-Iweala, N., \& Osafo-Kwaako, H. (2007). Nigeria's economic reforms: progress and challenges. Brookings Global Economy and Development Working Paper 6. Washington DC, The Brookings Institute. http://dx.doi.org/10.2139/ssrn.1080251 
Onwudiwe, E., \& Suberu, R. T. (2005). Nigerian federalism in crisis: critical perspectives and political options. Ibadan: John Archers Publishers Ltd.

Orren, K. (1991). Related feudalism: labour, the law, and liberal development in the United States. Cambridge: Cambridge University Press.

Osaghae, E. E., \& Onwudiwe, E. (2007). The management of the national question. Okada: Igbinedion University Press.

Pogoson, A. I. (2013). Nigeria national security in an age of terrorism. Ibadan: Maiden Departmental Lecture, Department of Political Science, Faculty of the Social Sciences, University of Ibadan.

Polet, F. (2007). The state of resistance: Popular struggles in the global south. London \& New York: Zed Books

Putnam, R. D., Leonardi, R., \& Nanetti, R. (1993). Making democracy work: civic traditions in modern Italy. Princeton, NJ: University Press Princeton.

Reinert, E. S. (1996). The Role of Technology in the Creation of Rich and Poor Nations: Underdevelopment in a Schumpeterian system. In D. H. Aldcroft, \& R. E. Catterall (Eds.), Rich Nations - Poor Nations. The Long-Run Perspective (pp. 161-188). US: Brookfield.

Rothschild, E. (1995). What is security? Daedalus, 124, 53-98.

Sheidu, A. D. (2004). Harnessing Nigeria's resources for the successful implementation of the National Economic and Empowerment and Development Strategy (NEEDS). Annual Lecture of the Chartered Institute of Bankers of Nigeria, Lagos.

Stolberg, A. G. (2012). How nation-states craft national security documents. US Army War College. Strategic Studies Institute. Monograph.

Suh, J., \& Chen, D. H. C. (2007). Korea as a knowledge economy: evolutionary process and lessons learned. Washington D.C: World Bank. http://dx.doi.org/10.1596/978-0-8213-7201-2

Suleiman, T. (2013). Robbing the jobless: some civil servants and their collaborators in the private sector exploit the high unemployment situation in the country to fleece desperate job seekers. Tell February, 18(7).

Tickner, J. A. (1995). Re-visioning security. In Booth K., \& Smith S. (Eds.), International Relations Theory Today. Oxford: Oxfrod University Press.

Todaro, P. M., \& Smith, S. C. (2011). Economic development. Addison-Wesley Pearson.

Umukoro, A. (2012). Hope for the youths: YouWIN initiative gives a lifeline for innovative youths to become entrepreneurs. Tell June, 12, Special Publication.

Waever, O. (1997). Concept of security. Copenhagen: University of Copenhagen.

Waever, O. (2000). What is security? The securityness of security. In B. Hansen (Ed.), European Security Identities-2000. Copenhagen: Copenhagen Political Studies Press.

Williams, P. (1994). Transnational criminal organizations and international security. Survival, 36, 96-113. http://dx.doi.org/10.1080/00396339408442726

Wyn Jones, R. (1999). Security strategy and critical theory. London: Lynne Rienner.

Yew, K. L. (2000). From third world to first: the Singapore story 1965-2000. New York: HarperCollins Publishers.

\section{Notes}

Note 1. He is vice chairman, Senate Committee on Establishment and Public Service.

Note 2. This point was extensively discussed by Iwu (2000: 40-46), Nigeria Economic Development in the $21^{\text {st }}$ Century: An Appraisal of the Role of Multinational corporations. Unpublished Bachelor of Science Degree Dissertation, Political Science Department. Ibadan: University of Ibadan.

\section{Copyrights}

Copyright for this article is retained by the author(s), with first publication rights granted to the journal.

This is an open-access article distributed under the terms and conditions of the Creative Commons Attribution license (http://creativecommons.org/licenses/by/3.0/). 